\title{
ENGLISH LISTENING PROFICIENCY AND FACTORS AFFECTING ENGLISH LISTENING SKILLS OF FIRST YEAR UNDERGRADUATE STUDENTS AT THAT PHANOM COLLEGE, NAKHON PHANOM UNIVERSITY
}

\author{
Ditthawat Thongsook \\ That Phanom College, Nakhon Phanom University, Thailand \\ Corresponding Email: kengkla17@hotmail.com
}

\begin{abstract}
This research is aimed at studying English listening proficiency and factors affecting English listening skills of first year undergraduate students at That Phanom College, Nakhon Phanom University. The study focused on two parts: 1.) factor related to the students and 2.) factor related to previous management of English teaching and learning andit also focused on seven aspects:1.) students' English knowledge and skill, 2.) students' attitude of English learning,3.) students' motivation of English learning, 4.) students' personality of using English,5.) students' opportunity of using English, 6.) teachers' previous arrangement of English teaching and learning, and 7.) teachers' previous teaching aspect. The subjects of this research were first year undergraduate students studying during the first semester of the academic year 2017at That Phanom College, Nakhon Phanom University. These subjects were 35 undergraduate students from two programs of study: Program of Energy Engineering and Program of Modern Trade Management. This research consists of two instruments for collecting data. The first instrument is the test of English listening based on CEFR or Common European Framework of Reference for Language and questionnaire which B1 level was used for testing English listening skill, and the second instrument is the questionnaire. Statistics used for analyzing data were frequency, percentage, mean, and standard deviation. Results of the study found that the mean score of English listening skill of the student was at low level. The factors affecting English listening skill of these students were both parts of students and previous management of English teaching and learning. For some of the students, the factors which caused the students' English listening skill were English knowledge and skill, personality of using English, and opportunity of using English. As attitude of English learning and motivation of English learning, they were not the factors affecting these students' English listening skill. In part of previous management of English teaching and learning, the factors caused the students' English listening skill were both previous learning and teaching management and previous teaching technique.
\end{abstract}

Keywords: Proficiency, Factor, English Listening Skill.

\section{Introduction}

In the current situation, the trend of globalization leads to closer relationships of each country. Certainly, communication is an important part for this relationship by which language is a mediate for communication. Languages in the world are different and various, more than 7,000 languages used in each region. English, Chinese, and Spanish are most widely spoken languages. However, English is only one language used for work and meeting in all world organizations (Marsh, 2012). This language is considered a universal language as English is widely used for international communication. Moreover, research, journals, textbooks and other information are mostly printed in English. These indicate that English plays a very important role in numerous sectors especially educational sector. The students, who are able to use English skills, will have an advantage over the others that cannot use 
those skills of English. They have more opportunities to continue in higher education and be promoted in their works (Safnil, 1991).

From four language skills (listening, speaking, reading, and writing), the skill which is mostly used for communication is listening. This skill is the process of decoding the expression. A listener uses this skill in order to make an understanding what a speaker is expressing. Listening skill is very important because it takes up $40-50 \%$, speaking is about $25-30 \%$, reading is about $11-16 \%$, and writing is about $9 \%$ (Gilakjani and Ahmadi, 2011). According to Ferris (1998), people spend $45 \%$ of time listening, 30\% in speaking, $16 \%$ in reading, and only $9 \%$ in writing in daily communication. This information shows that listening skill is very important for communication. To develop listening proficiency is the first step because it is the key to achieve other skills.

In Thailand, foreign language teaching and learning have been dramatically increased, especially for English. Numerous students spend a long time to learn English, but their English proficiency is still very poor. English listening is a main problem as numerous Thai students and other Thai people could not use this skill effectively when they communicated with English native speakers or foreigners who speak English (Wiriyachitra, 2002).

Ur (1996) specifies that there are some factors affecting speaking in English such as opportunity to use English and environment for using English etc. As Biyaem (1997), he points that the student cannot communicate in English effectively because they lack of opportunity to use English in daily lives. From stated reasons, the researcher was interested in investigating English listening proficiency and the factor affecting English listening skill of first year undergraduate students at That Phanom College, Nakhon Phanom University. The result of this research will benefit teaching and learning for developing English listening skill in That Phanom College, Nakhon Phanom University.

\section{Research Questions}

1. What was the level of English listening proficiency of first year undergraduate students at That Phanom College, Nakhon Phanom University?

2. Which factors affected English listening skill of first year undergraduate students at That Phanom College, Nakhon Phanom University?

\subsection{Purposes of the Study}

1. To investigate the level of English listening proficiency of first year undergraduate students at That Phanom College, Nakhon Phanom University.

2. To investigate the factors affecting English listening skill of first year undergraduate students at That Phanom College, Nakhon Phanom University.

\subsection{Scope of the Study}

1. This research investigated the level of English listening proficiency of first year undergraduate students at That Phanom College, Nakhon Phanom University.

2. This research investigated the factors affecting English listening skill of first year undergraduate students at That Phanom College, Nakhon Phanom University.

3. The subjects of this research were first year undergraduate students of That Phanom College, Nakhon Phanom University. The subjects were undergraduate students from two programs of study: Program of Energy Engineering and Program of Modern Trade Management.

4. The duration of this research was during May - August 2017. 


\subsection{Framework of the Research}

Independent Variables

1.) The Problem about English Knowledge and Skill

2.) The Problem about Attitude towards English Learning

3.) The Problem about Motivation for

Learning English

4.) The Problem about Personality of Using

English Skill

5.) The Problem about Opportunity of Using English Skill

6.) The Problem about Previous English

Learning and Teaching Management

7.) The Problem about Teaching Technique.
Dependent Variable

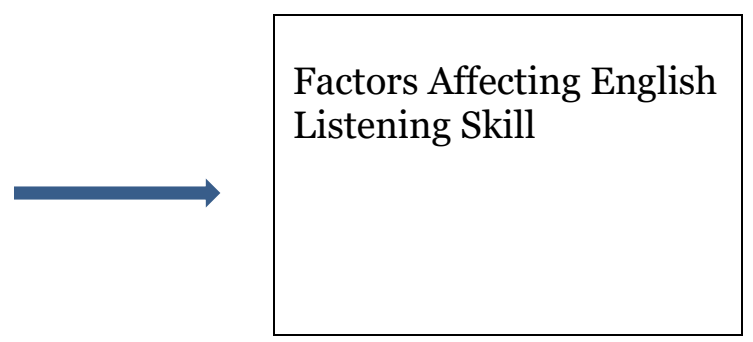

\section{Literature Review}

These are the concepts which involve the study of English listening proficiency and the problem of undergraduate students at That Phanom College, Nakhon Phanom University is as follows: Definition of Listening, Significance of Listening and Problem of Listening.

Definition of Listening

Listening skill is the ability to understand and identify or decode what a person is speaking about. It is the process that involves understanding pronunciation, tone, accent, grammar and the meaning of a speaker (Thomlison, 1984). Listening is listener's interaction with a speaker in order to decode or construct the meaning (Byrnes, 1984). The main point of listening is to comprehend an expression. Therefore, listening comprehension is a strategy to understand a speaker's meaning.

According to Ronald and Roskelly (1985), listening is an active process, not a passive process which the listener needs skills of prediction, generalizing, hypothesizing, checking and revising. They also state that listening relates to sound construction in order to make understanding what is heard.

As Howatt and Dakin (1974) defined listening as the ability to create and understand the meaning of an expression conveyed from the speaker. This part involves understanding the speaker's pronunciation, accent, grammar, vocabulary, and meaning. Thus, a listener needs to use these things simultaneously.

If people use listening skills effectively, they will understand the speakers' thinking or feeling well. Effective listening, listeners have to be actively involved to the process of communication.

\section{Significance of Listening}

Listening is the first process of language perception in children. It is not surprising that it plays an important role in language instruction. Also, listening plays a life - long role for the communication process (Rost, 2002). According to the study by Wilt (1950), it is found that $45 \%$ of people used listening skill, $30 \%$ for speaking skill, $16 \%$ for reading skill, and $9 \%$ for writing.

Learning comprehension is the way or process for acquiring or developing any language. In part of learning, listening skill is essential for learning because this skill provides comprehensible input for learner. The people who learn anything need to interact with the 
speakers to make understanding from what they hear (Krashen, 1989). Listening is an important skill. The people need to use it to interact with the speakers' expression for making understanding from what they are listening. Effective listening can lead to other languages development as well.

\section{Problem of Listening}

The Listening skill is very significant in daily lives. If the people cannot use this skill well, it is difficult to communicate. Lack of listening comprehension can lead to misunderstanding or poor result (Wenden, 1998). In the same point, Yagang (1994) pointed out that the problem involving listening skill were speaker, message, listener, and physical setting. As Nguyen (2002), specified, there were two problems effecting listening comprehension. Firstly, some people do not understand what they hear because they have never heard about that thing before or these people have no background knowledge about what they listen. Secondly, unfamiliar and too long messages are part of the listening problem as well.

For Underwood (1989), she pointed out that listening problem related to the listeners themselves. Those listeners need to have learning habit in the sense which they are encouraged by listening to the people who speak slowly and clearly.

Listening problems can occur due to various factors. One of those is the listeners. Some people lack of adequate listening skill, it can lead to misunderstanding. Background knowledge is also the factor effecting listening. If the listeners lack of background knowledge about what they are listening, it is difficult to understand about that thing.

\section{Research Methodology}

This part of research discusses the subjects of research, instruments of research, data collection, and data analysis.

\section{$\underline{\text { Subjects of Research }}$}

The subjects of this research were 35 first year undergraduate students from programs of Energy Engineering and Modern Trade Management studying in the first semester of academic year 2017 at That Phanom College, Nakhon Phanom University.

\section{Instruments of Research}

The instruments of this research consist of social English listening comprehension test and questionnaires which were designed and developed by the researcher as follows:

1.) Social English listening comprehension test, it contains 20 items. The researcher brought them from the textbook named interchange by Jack C. Richards, Jonathan Hull and Susan Proctor published in Cambridge University Press. These contents of the test are equivalent to B1 level (intermediate level) of CEFR (The Common European Framework of Reference of Language). CEFR is an international standard for describing English proficiency which is used around the world. For the result of the test, it can be assessed with the following criteria:

$$
\begin{array}{lll}
18-20 & = & \text { Excellent Level } \\
14-17= & = & \text { Good Level } \\
10-13= & = & \text { Fair Level } \\
5-9 & = & \text { Poor Level } \\
0-4 & = & \text { Very Poor Level }
\end{array}
$$

2.) Questionnaires about the factors affecting English listening skill were distributed. It was designed and divided into two parts; the general background information and the factors affecting English listening skills of the students. In part of the factors affecting English listening skills of the students, the five rating scales were used with the following criteria: 


$\begin{array}{lll}5 & = & \text { Very High Level } \\ 4 & = & \text { High Level } \\ 3 & = & \text { Moderate Level } \\ 2 & = & \text { Low Level } \\ 1 & = & \text { Very Low Level }\end{array}$

The students were asked for responding their opinion in each question of the questionnaire of the study.

After the researcher created the questionnaire initially, he distributed the questionnaire to 3 specialists for inspecting the validity through index of items objective congruence (IOC).

The formula of calculation is explained as follows:

$$
\mathrm{IOC}=\frac{\sum \mathrm{R}}{\mathrm{N}}
$$

IOC is the consistency between the objective and the question in questionnaire $\Sigma \mathrm{R}$ is the total score from all specialists

$\mathrm{N}$ is the number of specialists

For the value of an evaluation, it is explained as follows:

+1 shows that the question of questionnaire has validity

o shows that the question of questionnaire has uncertainty of validity

- 1 shows that the question of questionnaire has not validity

Actually, the score of each question in the questionnaire being evaluated by index of item objective congruence (IOC) should be between $0.50-1.00$. After the content validity of each question in questionnaire has been inspected from 3 specialists, the result specifies that the scores of each question in the questionnaire was between $0.60-1.00$. Thus, each question in the questionnaire of the study is suitable for use in this research.

Asa reliability test of the questionnaire of the study, questionnaire tryouts were used for testing with the different group of students. Cronbach's Alpha Coefficient was used for analysis. Actually, the confidence should be at least 0.70 (Thanachaiyakarn, 2012). After reliability of the questionnaire has been tested, the result specifies that the value of reliability of the questionnaire was 0.79 . Therefore, the questionnaire is suitable for using in the study.

\section{Procedures}

There are three steps for collecting data for this research as follows:

1.) 35 first year undergraduate students of That Phanom College, Nakhon Phanom University were assigned to do social English listening comprehension test for assessing their English listening skill

2.) After the students have done the test, the researcher distributed the questionnaires to these students for responding their opinion about the factors affecting English listening skill.

3.) In the last step, the students were interviewed about their opinions of problems of English listening.

\section{Data Analysis}

The statistics used in this study for statistical analysis are frequency, percentage, mean, and standard deviation. The statistics package for social science (SPSS) version 16.0 was used for analyzing data. 
$\underline{\text { Results of the Study }}$

The purposes of this research were to investigate the level of English listening proficiency of first year undergraduate students at That Phanom College, Nakhon Phanom University and to investigate the factors effecting their English listening skill.

1. The level of English listening proficiency of first year undergraduate students at That Phanom College, Nakhon Phanom University

Table 1: The Levels of Scores of Students' English listening Skill

\begin{tabular}{|c|c|c|}
\hline $\begin{array}{c}\text { Each level of Scores } \\
\text { (Full Score }=20 \text { points) }\end{array}$ & $\begin{array}{l}\text { Numbers of students who } \\
\text { received each level of } \\
\text { scores }(\mathbf{N}=35)\end{array}$ & $\begin{array}{l}\text { Percentages (\%) of student } \\
\text { who received each level of } \\
\text { scores }\end{array}$ \\
\hline Excellent (18 - 20 points) & $\mathrm{O}$ & $\mathrm{O}$ \\
\hline Good (14 - 17 points) & 1 & 2.85 \\
\hline Fair (10 - 13 points) & 7 & 20 \\
\hline Poor (5-9 points) & 24 & 68.57 \\
\hline Very Poor (o -4 points) & 3 & 8.57 \\
\hline Average Received Score & \multicolumn{2}{|c|}{$5-9$ points (Poor Level) } \\
\hline $\begin{array}{c}\text { Passed Number of } \\
\text { Students }\end{array}$ & \multicolumn{2}{|c|}{$8(22.85 \%)$} \\
\hline
\end{tabular}

From table 1, it indicates that averagely, the level of English listening proficiency of first year undergraduate students at That Phanom College, Nakhon Phanom University was at a low level. Scores of the most students $(68.57 \%)$ were at $5-9$ points out of 20 points, which it was poor level. This result also shows that there were only 8 students (22.85\%) out of 35 students that passed the test. The rest of another student's point was lower than half of full point.

2. The factors affecting English listening skill of first year undergraduate students at That Phanom College, Nakhon Phanom University

Table 2: The Factors affecting students' English listening skill

\begin{tabular}{|c|c|c|c|c|}
\hline \multirow[t]{2}{*}{ No. } & \multirow{2}{*}{$\begin{array}{l}\text { The Factor affecting } \\
\text { English listening skill }\end{array}$} & \multicolumn{3}{|c|}{$N=35$} \\
\hline & & $\begin{array}{l}\text { Mean } \\
(\bar{x})\end{array}$ & $\begin{array}{l}\text { Standard } \\
\text { Deviation } \\
\text { (S.D.) }\end{array}$ & $\begin{array}{c}\text { Frequency } \\
\text { Level }\end{array}$ \\
\hline 1 & $\begin{array}{l}\text { Problems about English } \\
\text { Knowledge and Skill }\end{array}$ & 4.04 & 0.009 & High \\
\hline 2 & $\begin{array}{l}\text { Problems about Attitude } \\
\text { towards English Learning }\end{array}$ & 2.35 & 0.516 & Low \\
\hline 3 & $\begin{array}{l}\text { Problems about Motivation } \\
\text { for English Learning }\end{array}$ & 1.62 & 0.125 & Low \\
\hline 4 & $\begin{array}{l}\text { Problems about Personality } \\
\text { of Using English Skill }\end{array}$ & 3.38 & 0.661 & Moderate \\
\hline 5 & $\begin{array}{l}\text { Problems about Opportunity } \\
\text { of Using English Skill }\end{array}$ & 4.05 & 0.115 & High \\
\hline 6 & $\begin{array}{l}\text { Problem about Previous } \\
\text { Learning and Teaching } \\
\text { Management }\end{array}$ & 3.62 & 0.242 & High \\
\hline 7 & $\begin{array}{l}\text { Problem about Previous } \\
\text { Teaching Technique }\end{array}$ & 3.29 & 0.161 & Moderate \\
\hline & Average & 3.19 & 0.261 & Moderate \\
\hline
\end{tabular}

From this table, itshows the factors affecting English listening skill of first year undergraduate students at That Phanom College, Nakhon PhanomUniversity. The details are 
explained as follows: problem about English knowledge and skill was at high level $(\bar{x}=$ 4.04), problem about attitude towards English learning was at low level ( $\bar{x}=2.35$ ), problem about motivation for English learning was at low level $(\bar{x}=1.62)$, problem about personality of using English skill was at moderate level $(\bar{x}=3.38)$, problem about opportunity of using English skill was at high level $(\bar{x}=4.05)$, problem about previous learning and teaching management was at high level $(\bar{x}=3.62)$, and problem about previous teaching technique was at moderate level $(\bar{x}=3.29)$.According to the result from table 2 , there were 5 factors from all 7 factors effecting English listening skill of first year undergraduate students at That Phanom College, Nakhon Phanom University as follows:

1.) Problem about English Knowledge and Skill

Problem about English knowledge and skill affected English listening skill of

first year undergraduate students at That Phanom College, Nakhon Phanom University in high level $(\bar{x}=4.04)$. The factors of problem about English knowledge and skill affecting their English listening skill were (1.) Students lacked of knowledge about adequate English vocabularies, (2.) Students lacked of knowledge about adequate English idioms and slangs, (3.) Students were not familiar to native speakers' pronunciation, (4.) Students lacked of adequate knowledge about English grammar, (5.) Students did not understand linked sound of English words, and (6.) Students did not understand the meaning if native speakers speak without using body language.

\section{2.) Problem about Personality of Using English Skill}

Problem about personality of using English skill affected English listening

skill of first year undergraduate students at That Phanom College, Nakhon Phanom University in moderate level $(\bar{x}=3.38)$. The factors of problem about personality of using English skill affecting their English listening skill were (1.) Students avoided watching English film, (2.) Students avoided communicate with native speaker, and (3.) Students worried when they communicate with native speakers.

\section{3.) Problem about Opportunity of Using English Skill}

Problem about opportunity of using English skill affected English listening skill of first year undergraduate students at That Phanom College, Nakhon Phanom University in high level ( $\bar{x}=4.05$ ). The factors of problem about opportunity of using English skill affecting their English listening skill were (1.) Students seldom had opportunity to communicate with native speakers, (2.) Students did not have relative or friend who can communicate in English well, (3.) Students seldom have opportunity to use English skill in classroom

\section{4.) Problem about Previous Learning and Teaching Management}

Problem about previous learning and teaching management affected English listening skill of first years undergraduate students at That Phanom College, Nakhon Phanom University in high level $(\bar{x}=3.62)$. The factors of problem about previous learning and teaching management were (1.) Students were seldom taught by native speaker, (2.) Learning and teaching medias were not used variously, (3.) Students were not trained in English listening adequately, (4.) Students did not have adequate chance to be trained English skill outside the classrooms, and (5.) Student did not have adequate chance to listen to the sound of native speaker through cd or another media.

\section{5.) Problem about Previous Teaching Technique}

Problem about previous teaching techniques affected English listening skill of first year undergraduate students at That Phanom College, Nakhon Phanom University in moderate level $(\bar{x}=3.29)$. The factors of problem about previous teaching technique were (1.) Teachers seldom spoke English in the classrooms, (2.) Teachers did not have adequate technique to make English easier, (3.) Teachers seldom motivated or activated students to learn English, (4.) Teachers did not emphasize listening in English, and (5.) Teacher 
emphasized using English grammar more than using English for communication. As the result from the open ended questions in questionnaires, most of the students specifies that inadequate knowledge about vocabulary, less opportunity to use English, and excitement and anxiety when using English were the main factors affecting their English listening skill.

\section{Discussion and Conclusion}

The aims of this research were to investigate the level of English listening skill of first year undergraduate students at That Phanom College, Nakhon Phanom University, and also investigate the factors affecting their English listening skill.

The result of the study indicates that the level of English listening proficiency of first year undergraduate students at That Phanom College, Nakhon Phanom University was at low level. Scores of the most students $(68.57 \%)$ were at $5-9$ points out of 20 points, which it was poor level. This result also shows that there were only 8 students (22.85\%) out of 35 students that passed the test. The rest of another student's point was lower than half of full point. For the result of factors affecting English listening skill of first year undergraduate students at That Phanom College, Nakhon Phanom University, it is explained as follows: problem about English knowledge and skill was at high level $(\bar{x}=4.04)$, problem about attitude towards English learning was at low level $(\bar{x}=2.35)$, problem about motivation for English learning was at low level $(\bar{x}=1.62)$, problem about personality of using English skill was at moderate level $(\bar{x}=3.38)$, problem about opportunity of using English skill was at high level $(\bar{x}=$ 4.05), problem about previous learning and teaching management in the past was at high level $(\bar{x}=3.62)$, and problem about teaching technique was at moderate level $(\bar{x}=$ 3.29).From the result of the factors affecting the students' English listening skill, it can be concluded that the factors affecting their English listening were the problem about English knowledge and skill $(\bar{x}=4.04)$, the problem about personality of using English skill $(\bar{x}=$ $3.38)$, the problem about opportunity of using English skill $(\bar{x}=4.05)$, the problem about previous learning and teaching management $(\bar{x}=3.62)$, and the problem about previous teaching technique $(\bar{x}=3.29)$.

For the result from the open ended questions in questionnaires of the study, most of students indicates that inadequate knowledge about vocabulary, less opportunity to use English, and excitement and anxiety when using English were the main factors affecting their English listening skill.

\section{Acknowledgement}

The researcher would like to thank the Personnel Development Funds, Nakhon Phanom University, Nakhon Phanom, Thailand for financial support. 


\section{References}

i. Biyaem, S., 1997. The child's concept of story. Illinois: University of Chicago Press.

ii. Byrnes, H., 1984. The role of listening comprehension: A theoretical base. Foreign Language Annuals, Volume 17, pp. 317-329.

iii. Ferris, D., 1998. Students' views of academic aural/oral skills: A comparative needs analysis. TESOL Quarterly, Volume 32, pp. 289-318.

iv. Gilakjani, A. \& Ahmadi, M., 2011. A Study of Factors Affecting EFL Learners English Listening Comprehension and the Strategies for Improvement. Journal of Language Teaching and Research, 2(5), pp. 977-988.

v. Howatt, A. \& Dankin, J., 1974. Language laboratory materials. Techniques in applied linguagtics. Edinburgh in applied linguistics. 3 ed. London: Oxford University Press.

vi. Krashen, S., 1989. Language acquisition and second language education. New York: Prentice Hall.

vii. Marsh, D., 2012. Blended learning: Creating learning opportunity for language learners. New York: Cambridge University Press.

viii. Nguyen, T., 2002. Cultural effects on learning and teaching in Vietnam: The Language Teacher. Language Annuals, Volume 26, pp. 2-6.

ix. $\quad$ Rost, M., 2002. Teaching and researching listening. London: Longman.

x. $\quad$ Safnile, 1991. Techniques for dealing with large English classed. Guidelines, 13(1), pp. 82-86.

xi. Tanachaiyakhan, N., 2012. Statistics for research. Bangkok, Thailand: Vidhayapat.

xii. $\quad$ Thomlison, T., 1984. Relational listening: theoretical and practical considerations. s.l., The Annual Meeting of the $5^{\text {th }}$ International Listening Association.

xiii. Underwood, M., 1989. Teaching Listening. New York: Longman.

xiv. Ur, P., 1996. A course in language teaching. Practice and theory. Cambridge: Cambridge University Press.

xv. Wenden, A., 1998. Language training in foreign/second language learning: A curricula perspective for 21st century. New York: York College of the City University of New York.

xvi. Wiriyachitra, A., 2002. English language teaching and learning in Thailand in this decade. Thai Tesol Focus, 15(1), pp. 4-9.

xvii. Yagang, F., 1984. Listening: Problems and solutions. In: T. Kral, ed. Teacher Development: Making and Right Moves. Washington DC: English Programs Division. 